\author{
Stefano ZOIA*
}

\title{
The Macrocoma Chapuis from the Canary Islands, with description of a new species (Coleoptera Chrysomelidae Eumolpinae)
}

\begin{abstract}
Riassunto: Le Macrocoma delle Isole Canarie, con descrizione di una nuova specie (Coleoptera Chrysomelidae Eumolpinae).
Le specie di Macrocoma note per le Isole Canarie sono riviste e ne vengono illustrati gli edeagi. Viene descritta Macrocoma pelikani n. sp. di Gran Canaria, Barranco de Guayadeque. M. franzi Palm, 1976 viene considerata sottospecie di M. splendidula (Wollaston, 1862) e sono proposti i seguenti cambiamenti nomenclatoriali: M. splendidula ssp. franzi Palm, 1976 n. stat., M. splendidula ssp. palmaensis Palm, 1977 n. stat. Sono inoltre fornite una chiave dicotomica per l'identificazione delle specie e un catalogo con nuovi dati geonemici.
\end{abstract}

\begin{abstract}
The known species of Macrocoma from the Canary Islands are reviewed and the aedeagi illustrated. Macrocoma pelikani n. sp. is described from Gran Canaria, Barranco de Guayadeque. M. franzi Palm, 1976 is downgraded to subspecies of M. splendidula (Wollaston, 1862) and the following nomenclatural changes are proposed: M. splendidula ssp. franzi Palm, 1976 n. stat., M. splendidula ssp. palmaensis Palm, 1977 n. stat. A key to species identification and a catalogue with new locality data are also provided.
\end{abstract}

Key words: Macrocoma, Canary Islands, new species, new status.

\section{INTRODUCTION}

I recently received from Jan Pelikan (Hradec Králové - Czech Republic) an interesting material of Macrocoma collected in Gran Canaria.

Up to now nine taxa have been ascribed to the genus Macrocoma from the Canary Islands. Eight of them were treated by Palm (1976) who also figured the aedeagi and provided a key to species. Subsequently Daccordi (1978) described M. oromiana from Alegranza and Salvajes Islands. More recently Warchalowsky (2001, 2003 and 2010) provided keys to the Palaearctic species of the genus Macrocoma, including the ones object of the present contribution.

Thanks to the kindness of the curators of different Museums and some friends, I had the opportunity to examine type specimens of eight of these taxa, together with other material of Macrocoma from the Canary Islands. I did not have the chance to examine any specimen of M. franzi palmaensis Palm, 1977, so this taxon is here treated on the basis of literature data only.

Based on the above I here describe a new taxon and I revise the other species providing a new key to species and Figures of specimens and aedeagi.

The following acronyms are used:

AMcoll - Antonio Machado Carrillo collection (Santa Cruz de Tenerife)
FMNH - Finnish Museum of Natural History, Helsinki JPcoll - Jan Pelikán collection (Hradec Králové, Czech Republic)

MDcoll - Mauro Daccordi collection (Verona, Italy)

MMcoll - Marion Mantič collection (Hlučín-Bobrovníky, Czech Republic)

MNHT - Museo de la Naturaleza y el Hombre, Museos de Tenerife

NHML - The Natural History Museum, London

NHMW - Naturhistorisches Museum Wien

OUMNH - Oxford University Museum of Natural History

SZcoll - Stefano Zoia collection (Milan, Italy)

\section{RESULTS}

Macrocoma species from the Canary and Salvajes Islands are all endemic of these islands; these species are strictly related each other and not easy to discriminate, sharing important characters, i.e. small differences in body size, kind of pubescence of the elytra (in most cases with 9 longitudinal stripes of adpressed setae, separated by partially erected ones, all setae being flattened and more or less hyaline), relative oblong legs and moderately short antennae, sameness about spermathecal morphology, aedeagi with the apex divided by a short cut or a saddle-like impression. All these features suggest the complex

*Stefano Zoia, via Ponte Nuovo 109/4, 20128 Milano, Italy. E-mail: stefano.zoia@chrysomelidae.it 
could be monophyletic, being the result of a single colonization event.

Nevertheless, aedeagic morphology allows to discriminate three groups of taxa:

- a group M. divisa/oromiana/dubia/latifrons with the aedeagus characterized by a more rounded apex, with a short saddle-like notch (Figs. 3, 5, $11,15,17,21,23,25)$. These taxa are morphologically more differentiated each other than the ones in the other groups. They have reduced mesothoracic wings, with the exception of M. latifrons which is normally winged. A less sclerified dorsal side of abdomen is frequently, but not exclusively, linked to reduction of mesothoracic wings in the Eumolpinae and here is the case. The brachypterous species are present in the Eastern Islands (Fuerteventura, Lanzarote, Graciosa, Alegranza) and in Salvajes I., while M. latifrons is known from Tenerife (Fig. 70);

- M. obscuripes and M. pelikani n. sp. are similar in edeagic characteristics, with a short V-shaped cut at the apex (Figs. 28, 37, 38); both are winged and inhabit Gran Canaria (Fig. 70). Similar aedeagic features are shown by $M$. splendens (Tenerife and La Palma, Fig. 65), with a characteristic short distal production of the apex at both sides of the incision (Figs. 42, 45);

- a complex M. splendidula/franzi/palmaensis, which inhabits the Central-Eastern part of the archipelago (Gran Canaria, Tenerife, La Palma, El Hierro) (Fig. 71), characterized by a longer distal part of the aedeagus, from the opening of the ostium to the apex, and a more or less deep, but narrow cut at the apex (Figs. 49, 51, 53, 56, 60). These taxa are winged, they are very similar each other in exoskeletal morphology and hardly distinguishable.

I had the opportunity to study and compare type specimens of $M$. splendidula and $M$. franzi franzi, together with other specimens of both taxa collected in different localities as reported below. Differential characteristics mentioned by Palm (1976) (punctuation and brilliance of head, pronotum and elytra, color of antennae and legs) are subject to a variability inside each population. In my opinion, that overcomes any possibility to distinguish specimens from different Islands, except for some differences in the average body size and frequency of more or less dark coloration of the dorsum. As already arguable from Figures provided by Palm (1976: figs $4 \mathrm{~d}, 4 \mathrm{~g} / \mathrm{i})$, the aedeagi show no significant differences (Figs. 49-53, 56-57, 60-61), with a feeble variation in the depth of the incision at the apex, which is usually a little less deep in the typical M. splendidula, although not so evident as drawn by Palm, 1976.

I did not get a chance to study any specimen of $M$. franzi palmaensis, neither to find any type specimen in the OUMNH collection nor elsewhere. Palm (1976) described this taxon with the name $M$. occidentalis and subsequently renamed it as M. palmaensis Palm, 1977 to correct the homonymy with M. henoni occidentalis (Escalera, 1914). In my opinion, the original description and illustration of aedeagus (Fig. 4f in Palm, 1976, here reproduced in Figs. 60 and 61) do not highlight any significant difference from ssp. franzi.

Based on these facts, and considering a possibility that more accurate studies, particularly the examination of M. f. palmaensis, might prove some differences between the populations from different Islands, I prefer to maintain here these names with a status of subspecies and I propose the following nomenclatural changes:

Macrocoma splendidula ssp. franzi Palm, 1976 n. stat. pro M. franzi ssp. franzi Palm, 1976

Macrocoma splendidula ssp. palmaensis Palm, 1977 n. stat. pro M. franzi ssp. palmaensis Palm, 1976.

To my knowledge, no Macrocoma has ever been reported for La Gomera and I have not seen specimens from this Island until now, which is for sure due to lack in researches.

\section{KEY TO SPECIES}

As it frequently happens in the genus Macrocoma, very few exoskeletal characters are so reliable to give unambiguous choices in a key to species when close taxa are involved; body size, habitus, colour pattern, punctuation and microreticulation of integuments always show inconstancy and an incautious use can lead to incorrect attributions. This reflects on the uncertain status of the taxonomy of the genus and it could affect the reliability of identifications based on exoskeletal characteristics only.

Referring to the Macrocoma of the Canary Islands, an accurate examination of the aedeagi, in par- 
ticular of the outline of the apex, is really helpful and sometimes necessary to discriminate species. Examined spermathecae are quite uniform (Figs. 62-64, 6669), showing some differences mainly in the length of the spermathecal gland: the shortest in M. obscuripes and $M$. pelikani n. sp. confirming the closeness of these species; longer, but not exceeding the spermathecal body length in $M$. divisa and $M$. splendens; as long as the spermathecal body or longer in $M$. latifrons, M. s. splendidula and M. s. franzi.

A molecular approach to the taxonomy of the group could give in the future its contribution.

The following key is intended for the Macrocoma of the Canary Islands only. The length of body includes the head, with the proximal edge of eyes close to the distal edge of pronotum.

1 Elytra relatively short and more regularly convex at sides and along the suture; humeral calli poorly developed, scutellum semicircular.

1' Elytra proportionally longer, usually more or less flattened at base near the suture and usually transversally impressed on the basal third; elytral sides feebly convex or subparallel in the basal third (not in males of M. dubia, which can be separated for the brown color of the dorsum with the distal margin of pronotum paler)

2 Smaller species, length $2.6-3.5 \mathrm{~mm}$; antennae nearly uniformly reddish-brown, sometimes with antennomeres 7-11 somewhat darker, brachypterous (wings reaching the elytral apex in females, nearly half so long in males); aedeagus as in Figs. 3-4, habitus as in Figs 1-2, 7-8 (Fuerteventura, Lanzarote, Graciosa) ......... divisa (Wollaston, 1864)

2' Body length 3.8-4.4 mm, antennal segments 7-11 darker than 1-6, brachypterous; aedeagus as in Figs. 11-12, habitus as in Figs. 9-10 (I. Alegranza, I. Salvajes) ................ oromiana Daccordi, 1978

3 Antennae and legs blackish with metallic reflections, antennomeres $2-5$ sometimes partially reddish; length $2.8-4.2 \mathrm{~mm}$; aedeagus as in Figs. 28-29, habitus as in Figs. 26-28 and 30 (Gran Canaria)...... obscuripes (Wollaston, 1864)

3' Antennae and legs in part or entirely reddish .....4

4 Antennomeres 2-6 reddish at base, blackish distally; femora black with metallic reflections, tibiae reddish, tarsi brown to black; punctuation of pronotum relatively strong and partially confluent, stronger than on elytra; length $2.6-3.4 \mathrm{~mm}$; aedea- gus as in Figs. 37 and 38, habitus as in Figs. 31 and 32-33 (Gran Canaria)................pelikani n.sp.

4' Not as above; antennae and legs in large part or entirely reddish

5 General aspect less elongated with elytra more convex both dorsally and on the elytral sides, humeral calli less prominent and poorly separated from the adjacent elytral surface; dorsum brown to dark brown without metallic hue, the distal edge of pronotum paler; length $3.0-4.3 \mathrm{~mm}$; aedeagus as in Figs. 15-17, habitus as in Figs. 13-14 (Fuerteventura, Lanzarote).... dubia (Wollaston, 1864)

5' General aspect more elongated with elytra nearly flat or feebly convex on discus and sides subparallel on the basal third; humeral calli more prominent and separated by the adjacent elytral surface by a more evident impression; dorsum metallic .....................6

6 Antennae and legs reddish; elytra oblong with sides almost parallel up to mid-length; coloration of pronotum and elytra metallic green to bronze; length 3.1-4 mm; aedeagus as in Figs. 42-43 and 45-46, habitus as in Figs. 40-41 and 44 (La Palma, Tenerife)...... splendens

6' Antennomeres 7-11 and femora usually more or less darkened.

7 Maximum width of pronotum in males at level of the basal third or in the basal half; coloration usually darker, metallic, bronze to piceous, rarely lighter and greenish; length 33-44 mm; aedeagus as in Figs. 21-25, with a wide impression at its apex, habitus as in Figs. 19 and 20 (Tenerife) ................. latifrons

7' Maximum width of pronotum at about midlength, sides more regularly bent throughout; coloration usually lighter, metallic green to bronze; aedeagus with a thin split at its apex ................................... 8

8 On average body size somewhat bigger, length 3.5$4.4 \mathrm{~mm}$; aedeagus as in Figs. 49-53, habitus as in Figs. 47 and 48 (Gran Canaria, Tenerife). splendidula ssp. splendidula

8' On average body size smaller, length 3.2-4.1 mm; aedeagus as in Figs. 56-57, habitus as in Figs. 54, 55 and 58-59 (El Hierro) ..splendidula ssp. franzi

8" [Halsschild und Flügeldecken kürzer und breiter (compared to splendens!). Halsschild feiner und weitläuFiger, Flügeldecken viel feiner punktiert. Flügeldecken mit gedämpftem Glanz, ihre Behaarung etwas kürzer. Länge 3,9-4,0 mm (Palm, 1976)] aedeagus Figs. 60 and 61 (La Palma) splendidula ssp. palmaensis 


\section{CATAlogue And Notes}

A large part of mentioned material has been seen by the author, a few data are reported from literature as indicated.

\section{Macrocoma Chapuis, 1874}

Macrocoma divisa (Wollaston, 1864) (Figs. 1-8, 62) Pseudocolaspis divisa Wollaston, 1864: 394

TYPE SPECIMENS. 19 Syntypes OUNHM (examined) labelled: standing over: Pseudocolaspis divisa Wollaston, 1864 Cat. Col. Ins. Can. Coll. B.M.: 394-95 / Wollaston Canary Colln. Lanzerote OUMNH-2006009; 1 ㅇ Syntype NHML (examined) labelled: Syntype / Type / Pseudocolaspis divisa, Woll. Type.

DisTRIBUTION AND GEONEMIC DATA. Lanzarote: ["Lanzarotam borealem, sub lapidibus in aridis, rarissima" (Wollaston, 1864)]; Lanzarote lg. H.Franz / Canarische Inseln leg. H. Franz (1 $q$ NHMW). Fuerteventura: Fuerteventura Canarias Jandia: Valle de los Mosquiitos, $50 \mathrm{~m}$, 9-3-2011, leg. Antonio

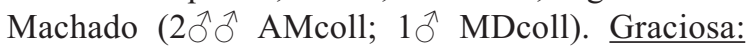
(Palm, 1976)

Note. The aedeagus of the male Syntype is drawn in Figs. 3 and 4. A population from Fuerteventura somewhat differs in the morphology of the aedeagus (Figs. 5 and 6), having a wider incision at the apex and lightly bent sides in dorsal view. Examined male specimens do not allow me to decide for a separation among the populations of different islands.

Macrocoma dubia (Wollaston, 1864) (Figs. 13-18) Pseudocolaspis dubia Wollaston, 1864: 395

TYPE SPECIMENS. 2 우 OUNHM Syntypes (examined) labelled: R.P / standing over: Pseudocolaspis dubia Wollaston, 1864 Cat. Col. Ins. Can. Coll. B.M.: 395 / Wollaston Canary Colln. Fuerteventura OUMNH2006-009; 1 Syntype NHML (examined) labelled: R.T / Syntype / Type / Pseudocolaspis dubia, Woll. type. DistRIBUTION AND GEONEMIC DATA. Fuerteventura: [Fuerteventuram, Aprili ineunte A.D. 1859 in Rio Palmas capta (Wollaston, 1864)]. Lanzarote: Los An-

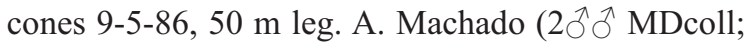
1ठ, 2 우 AMcoll); Lanzarote, Los Ancones 9-V-86 Machado (3ðึ, 7 우우 MNHT)

Note. The aedeagus in this species is characterized, in dorsal view, by the straight, convergent sides and the relatively narrow apical zone. A relatively large variability in these characteristics was detected in specimens from Los Ancones (Lanzarote), as in Figs. 15-18.

Macrocoma latifrons Lindberg, 1953 (Figs. 19-25, 69) Macrocoma latifrons, Lindberg, 1953: 10 M. vicina Lindberg i.l.

TYPE SPECIMENS. $\delta$ Holotype FMNH (examined) labelled: Tenerife Puerto de S. Juan 23.2.50 Lindberg / Macrocoma latifrons m. Harald Lindb. det. / Mus. Zool. H:fors Spec. typ. No 2606 Macrocoma latifrons Har. Lindb. / Photographed 2016 Pekka Malinen / http://id.luomus.fi/GAC.21681 / http://id.luomus.fi/ GAC.21681 Macrocoma latifrons Lindberg $1953 \mathrm{H}$. Lindberg det.; 3 paratypes FMNH (not examined): Tenerife, Puerto de S. Juan, 23.2.50, H. Lindberg; 5 paratypes FMNH $(2 \hat{\jmath} \hat{\jmath}, 1 q$ examined): Tenerife, J.M. Fernandez, Las Galletas, 24.2.1951; $10^{\widehat{N}}$ paratype FMNH (examined): Dr. C. O. v. Regteten Altena, Los Cristianos, Tenerife, 19-IV-1947.

Distribution AND GeONEMIC DATA. Tenerife: Tenerife (Is. Canarias) Playa S. Juan - Guía, km 6, 27.4.94, en Schyzogine s., leg. A. Machado, $250 \mathrm{~m}(2 \hat{\jmath} \widehat{\jmath}, 1$ 우 AMcoll); Tenerife, El Médano, 5-5-1968, J. M. Fernández

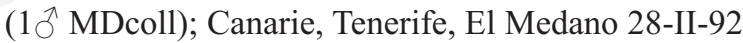
leg. Osella, Biondi, Altea (1 $\widehat{\jmath}$ MDcoll); Tenerife, Galletas 26-2-949 J. M. Fernández (1 $\overbrace{}^{\lambda}$ MDcoll); Tenerife Malpaís de Güímar, El Socorro, Bastazo Y Vela leg., 25/02/2016, $50 \mathrm{~m}, 28^{\circ} 19.565^{\prime} \mathrm{N} 16^{\circ} 22.208^{\prime} \mathrm{W}\left(10^{\top}\right.$, 5 우우 MDcoll; $1 \delta^{\lambda}, 1$ 우 SZcoll); Tenerife, Herjos [=

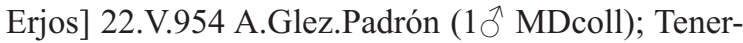

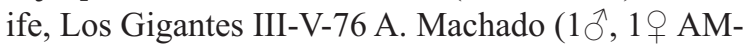
coll); Canary Islands, Tenerife, $50 \mathrm{~m}$, Playa de las Americas, leg. M. Mařík 17.4.2011 (1ठ JPcoll); Isole Canarie, Tenerife, Lower zone, IV.1991 leg. Beretta (1 $\hat{\jmath}, 1$ ㅇ MDcoll); Canarie Tenerife, Tamaimo dint.,

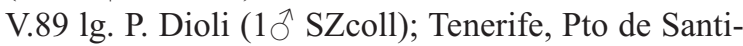
ago (2우 SZcoll); South Tenerife, Adeje 1-8.03.2001,

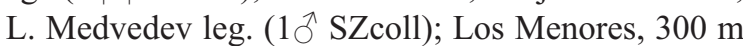
(Palm, 1976); Puerto de S. Juan (Palm, 1976); Los Cristianos (Palm, 1976); Las Galletas (on Hypericum canariense) (Palm, 1976).

Note. A ${ }^{-}$in NHML (examined) is labelled: Paratype / Tenerife, Puerto de S. Juan, 23.2.50 Lindberg / Macrocoma vicina n. sp. Harald Lindb. det. This is, without any doubt, a M. latifrons, possibly even collected together with the type specimens of the latter. The name vicina must be regarded as a not published perhaps provisional name, successively changed by Lindberg in latifrons. 
The aedeagus in this species is characterized by the wide saddle-like incision of the apex and by the sides clearly sinuate in dorsal view. Variability in the morphology of the aedeagus is shown in Figs. 21-25.

\section{Macrocoma obscuripes (Wollaston, 1862) (Figs. 26- 30, 64)}

Pseudocolaspis obscuripes Wollaston, 1862: 441

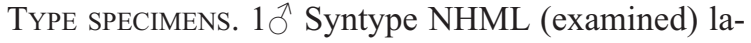
belled: Syntype / Type / Pseudocolaspis obscuripes type Woll.; $1{ }^{\lambda}$ Syntype NHML (examined) labelled: Syntype / Type / standing as Pseudcolaspis obscuripes Woll. (further 9 Syntypes in NHML, not examined) Distribution AND GeONEMIC DATA. Gran Canaria: ["in montibus excelsis Canariae Grandis, ad flores Cistorum (sc. C. monspeliensis et vagantis) capta" (Wollaston, 1862)]; Gran Canaria, Artenara, $360 \mathrm{~m}$,

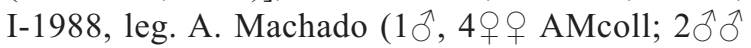
MDcoll); E Gran Canaria Isl., San Bartolomé 1,5 km S 18.2.2015 lgt. Jan Pelikán, 2754'43,6N $15^{\circ} 34^{\prime} 22,6 \mathrm{~W} 930 \mathrm{~m}$, sukul. buš. individ. sběr oklep vegetace [succulent bush, individual collecting, beating vegetation] (1 0 JPcoll); Gran Canaria, Maspalomas, N. Barr. de Chamoriscan, 300 m, 10.02.1997

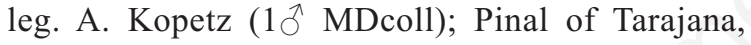
above San Bartolomé on Cistus vagans and monspeliensis (Palm, 1976)

Macrocoma oromiana Daccordi, 1978 (Figs. 9-12) Macrocoma oromiana, Daccordi, 1978: 156 TYPE SPECIMENS. $\widehat{\jmath}$ Holotype MNHT (examined): Alegranza, Islas Canarias, C. Gonzalez coll. / Holotypus / Macrocoma oromiana n. sp. det. Daccordi '77; ㅇ Allotype MNHT (not examined): Alegranza, Islas Canarias, 14.IV.54, leg. C. González; ㅇ Paratype MNHT (not Examined): Islas Salvajes, Salvaje Grande, 24, 25-II-1976, leg. P. Oromí.

DistRIBUTION AND GEONEMIC DATA. Alegranza. Islas Salvajes: Salvaje Grande (Daccordi, 1978)

NoTE. I examined only the holotype, which is highly damaged with antennae, the left fore leg and two tarsi missing (Figs. 9-10). It looks very similar to $M$. divisa in its habitus, mainly differing in larger body size. Looking at this specimen only, the punctuation of pronotum and elytra does not differ from what can be observed in specimens of $M$. divisa. The aedeagi of these two species are very similar, showing some differences in the morphology of the apex (Figs. 3-6 and 11-12).
Macrocoma pelikani n.sp. (Figs. 31-36, 65-66)

TYPE SPECIMENS. Holotype $\widehat{\sigma}$ MNHT: E - Gran Canaria Isl., Ingenio, $35 \mathrm{~km} \mathrm{~W}$ Bco. de Guayadeque, 2.2.2016 lgt. J. Pelikán [white printed label]; $27^{\circ} 55^{\prime} 34.2^{\prime \prime} \mathrm{N} 15^{\circ} 27^{\prime} 45.4^{\prime \prime} \mathrm{W}, 382 \mathrm{~m}$, sukul. buš, oklep [succulent bush, beating] Lavandula multifida canariensis [white printed label]; Holotypus Macrocoma pelikani n.sp. S. Zoia det. 2016 [printed red label].

Paratypes (13ßð, 8 우): E - Gran Canaria Isl., Ingenio, $35 \mathrm{~km} \mathrm{~W} \mathrm{Bco.} \mathrm{de} \mathrm{Guayadeque,} \mathrm{2.2.2016} \mathrm{lgt.} \mathrm{J.}$ Pelikán / 27 $55^{\prime} 34.2^{\prime \prime} \mathrm{N} 15^{\circ} 27^{\prime} 45.4^{\prime \prime} \mathrm{W}, 382 \mathrm{~m}$, sukul.

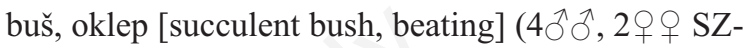

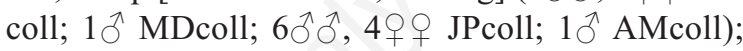
Spain, Gran canaria ins., Barranco de Guayadeque, 2,5 km WWN of Ingenio / $27^{\circ} 55^{\prime} 34^{\prime \prime} \mathrm{N} 15^{\circ} 27^{\prime} 45^{\prime \prime} \mathrm{W} 400$ m Mantič lg 25.03.2016, beeting Lavandula multifida (1 $\widehat{\jmath}, 1$ ㅇ MMcoll); E-Gran Canaria, Ingenio, B.co de Guayadeque, $382 \mathrm{~m}, 27^{\circ} 55^{\prime} 34.2^{\prime \prime} \mathrm{N} 15^{\circ} 27^{\prime} 45.4^{\prime \prime} \mathrm{W}$ lgt. J. Krátký (1 1 JPcoll).

Diagnosis. A Macrocoma species close to M. obscuripes (Wollaston, 1864) from which mainly differs in the smaller body size, shape of scutellum, color of antennae and legs, morphology of the aedeagus.

DeSCRIPTION. Habitus as in Figs. 31-33; body length of the holotype $3.0 \mathrm{~mm}$, of the paratypes 2.7-3.4 ( $\left.\delta^{\lambda}\right)$, 2.6-3.2 (우).

Body, head, pronotum and elytra dark, with metallic bronze reflections; labrum black, mandibles dark brown, palpi brown with darker distal segment; 1 st antennomere dorsally dark, usually with some metallic hue, 2nd to 6th antennomeres reddish at base and blackish distally, sometimes 5th and 6th nearly completely black, 7th to 11th black (Fig. 35); femora black with bronze metallic reflections, tibiae reddish, tarsi from brown to black, usually with base of the 1 st and last tarsomere paler .

Frons moderately and regularly convex; pubescence of frons and clypeus relatively long, thin, silvery; punctuation moderately strong, partially confluent on the vertex, sparse; surface between punctures smooth; clypeus not separated from frons, its distal border concave. Penultimate article of maxillary palp nearly so long as wide, the ultimate conical, nearly 1.7 times longer than the penultimate. First antennomere nearly twice longer than wide, as long as the 2 nd and nearly 1.5 times in diameter, feebly bent on the outer side; 2nd twice longer than wide; 3 th 0.6 times as long as the $2 \mathrm{nd}, 1.5$ times longer than wide; 
4th and 5th subequal to the 3th; 6th a little wider and shorter than the 5 th; 7 th to 10 th widened, the 7 th the longer, 8th to 10th a little wider than long; 11th 1.5 times longer than wide. Relative lengths of antennomeres in the left antenna of holotype: 1.8-1.6-1.21-1.2-1.1-1.4-1.3-1.3-1.3-2 (Fig. 35).

Pronotum 1.1-1.2 times wider than long $(1.1 \times 1.0 \mathrm{~mm}$ in the holotype), maximum width nearly at $1 / 3$ of the length; base a little wider than distal edge, the latter finely bordered; lateral margin obsolete; proximal angles marked by the insertion of a seta, not produced outwards; surface closely punctured, transversely rugose at sides; pubescence relatively long and thin, adpressed, sparse, hyalin (Fig. 34).

Scutellum vaguely pentagonal, apex somewhat rounded, shiny, with a few punctures and some hairs.

Hypomeron closely punctured and densely hairy, separated from the prosternum by an elevated carina; distal margin of hypomera and prosternum concave, regularly bent; prosternum wide, 1.2 times longer than wide between the coxae, moderately transversally elevated in the middle, strongly punctate, with sparse silvery pubescence.

Mesoventrite a little wider than prosternum between the coxae, its distal edge feebly bent, surface punctured, with fine sparse pubescence; mesoepimera punctured, pubescent.

Metaventrite punctured, finely transversally rugose, pubescent, distal border incised in middle; metacoxae a little more spaced than mesocoxae; metaepisterna tapering to rear, nearly 2.8 times longer than wide, punctured and densely pubescent.

Elytra convex, oblong, a little longer than wide (in the holotype: elytral length in dorsal view $1.7 \mathrm{~mm}$, distance from the base of scutellum to elytral apex $2.0 \mathrm{~mm}$; maximum width $1.6 \mathrm{~mm}$, width at base $1.5 \mathrm{~mm}$ ), on the basal half somewhat flattened near suture and with transversal posthumeral impressions); humeri protruded, covering the elitral sides in dorsal view; elytral sides nearly straight and feebly widened to rear from the base up to nearly half their length; apices in a right angle; punctuation (Fig. 34) moderately strong, a little stronger than on pronotum, close, sparse; surface smooth between the punctures; each elytron with nine longitudinal rows of adpressed hyalin/whitish setae, each row with a single seta on its width, separated by wider strips of moderately elevated hyalin hairs which reflect the color of the elytral surface. Epipleura moderately wide, gradually tapering to rear, smooth, with a line of fine hairs. Wings fully developed.

Legs relatively long; femora unarmed, moderately swollen; tibiae nearly straight, with a fine silvery pubescence. Protarsi a little widened in males (Fig. 36), the mesotarsi less so. Claws bifid, with the inner tooth a little shorter, the division starting at the basal third of the claw (meso- and metatarsi) or in the distal half (protarsi in males).

Dorsal side of abdomen sclerotized; abdominal ventrites punctured, with a very fine microreticulation and hyalin pubescence.

Aedeagus as in Figs. 37-39, the apex with a short but relatively wide incision in the middle.

Spermatheca as in Fig. 66, with a small prechamber at the insertion of the ductus; styli short, conical, poorly sclerotized (Fig. 65); spiculum gastrale moderately long (Fig. 65).

DeRIVATIO NOMINIS. The new species is dedicated to Jan Pelikán who collected and gave me for study the related material.

Note. M. pelikani $\mathrm{n}$. sp. was collected on shrubs of $L a$ vandula multifida canariensis (L.) Mill. (Lamiaceae).

M. pelikani n. sp. (Figs. 31-33) strictly resembles M. obscuripes (Wollaston, 1862) (Figs. 26, 27 and 30 ), with elytral sides feebly widened from the base to their mid-length and restricted to rear in a regular arch, yet its habitus is in general somewhat stouter; the pubescence of elytra is of the same type in both species, made of erected hyalin scale-like setae, with nine nearly regular longitudinal stripes of adpressed scale-like hyalin-whitish setae (Fig. 34). M. pelikani n. sp. differs in the average smaller body size (2.6-3.4 $\mathrm{mm}$ vs. 2.8 $4.2 \mathrm{~mm}$ ), tibae and base of $2 \mathrm{nd}$ to 5 th antennomeres reddish (black in $M$. obscuripes), aedeagus smaller with different shape of the apex (Figs. 28, 29 and 37-39).

Macrocoma splendens Lindberg, 1950 (Figs. 40-46, 68) Macrocoma splendens, Lindberg, 1950: 13

TYPE SPECIMENS. $\widehat{\jmath}$ Holotype FMNH: Tenerife, supra Icod, 9.V.47, H. Lindberg / Mus. Zool. H.fors Spec. typ. No 2514 Macrocoma splendens Har. Lindb. / Photographed 2016 Pekka Malinen / http://id.luomus.fi/GAC.21688

http://id.luomus.fi/GAC.21688 Macrocoma splendens Lindberg 1950 H. Lindberg det.; 18 Paratypes FMNH ( $2 \widehat{\widehat{\partial}}, 4$ 우 우 examined): Tenerife, Agua Mansa, 15.V. 47, H. Lindberg; 1 Paratype NHML (not examined): same data. 
Distribution And Geonemic Data. La Palma: La

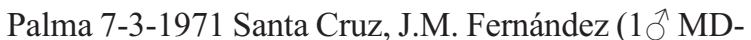
coll); I La Palma, Belhoco [= Velhoco] 23-V-72 J.M. Fernández (1 $\widehat{\jmath}$ MNHT); Hoyo Mazo, $300 \mathrm{~m}$ (Palm, 1976). Tenerife: Icod de los Vinos, $400 \mathrm{~m}$ (Palm, 1976); Agua Mansa, 1000 m (Palm, 1976)

\section{Macrocoma splendidula ssp. splendidula (Wollaston, 1862) (Figs 47-53, 63) \\ Pseudocolaspis splendidula, Wollaston, 1862: 442}

TYPE SPECIMENS. $\widehat{\delta}$ Lectotype NHML (examined) labelled: Syntype / Type / Lectotypus Th. Palm design.

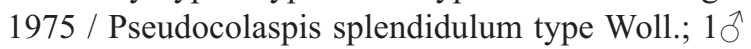
$4 ㅇ ㅜ$ NHML Paralectotypes T. Palm des. (not examined); further 4 Syntypes NHML (Wollaston's syntypes) (not examined)

DisTRIBUTION AND GEONEMIC DATA. Gran Canaria: [Gran Canaria "ad flores Cistorum in locis inferioribus et subinferioribus degens" (Wollaston, 1862)]; Gran Canaria, Canarias, Telde: Mña El Goro 28-1-2016 Sobre Malva, leg. Antonio Machado / AMC (1 $q$ AMcoll); Gran Canaria, España, Tufia, 21-3-2010, arenal Schyzogine sericea, leg. Antonio Machado (1우 AMcoll); E - Gran Canaria Isl., Tufia (Atlantic coast) 28.1.2016 lgt.

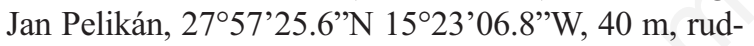
erál nočni osmyk [ruderal vegetation, night sweeping] Patellifolia patellaris (1 $\hat{0}, 2$ 우 JPcoll); Maspalomas

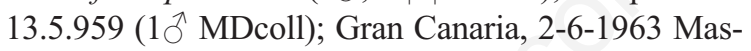
palomas J.M. Fernández ( $2{ }^{\lambda} \sigma^{\lambda}$ MNHT); Gran Canaria, Maspalomas; Arguineguin (on Schizogyne sericea) (Palm, 1976); Gran Canaria, Playa de Arinaga (on Bassia tomentosa) (Jan Pelikan in verbis). Tenerife: Tenerife, Islas Canarias, Malpaís de Güímar, 30 m, 26-

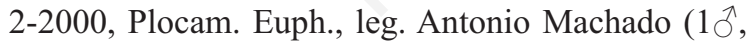
3 오 AMcoll); Tenerife 10.3.1963 S. Andrés J.M. Fer-

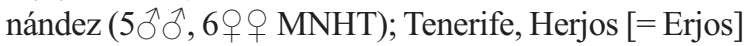
22.V.954 A. Glez. Padrón (1 9 MNHT); Tenerife 24-2951 Las Galletas J.M. Fernández (3 $9+$ MNHT); Tenerife, El Médano 16-4-1976 J.M. Fernández (1우 MNHT); Tenerife, Tamaimo 27-5-54 A. Gonzalez (1우 MNHT); Tenerife 3-4-1960 B.co Santos J.M. Fernán-

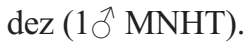

Macrocoma splendidula ssp. franzi Palm, $1976 \mathrm{n}$. stat. (Figs. 54-59, 67)

M. occidentalis franzi, Palm, 1976: 102
TYPE SPECIMENS. $\delta$ Holotype NHMW (examined): Isla del Hierro, Restinga / Sp 1181 / Kanarische Inseln leg. H. Franz / M. occidentalis franzi Palm Det. Th. Palm / Holotypus [Palm, 1976 added the following data: (nahe Küste) 23-25.3.68]; ㅇ Allotype NHMW (examined): Isla del Hierro, Restinga / Kanarische Inseln leg. H. Franz / Allotypus; $1 \hat{\jmath}$, 4 우우 Paratypes NHMW (1 $\hat{\jmath}$ examined): Isla del Hierro, Las Playas, lg. Franz / Sp 1324 / Paratypus; 10, 4 우우 Paratypes NHMW (not examined): Isla del Hierro, Restinga / Kanarische Inseln leg. H. Franz; $10^{\lambda}$ Paratype NHMW (not examined): El Brezal, etwa $800 \mathrm{~m}, 22.3 .68$.

Distribution AND GEONEMIC DATA. Hierro: Isla del Hierro, Restinga, Kanarische Inseln, leg. H. Franz (1 우 MDcoll; 1 ô, 1 q SZcoll); Isla del Hierro, El Golfo Lorbeerwald, Kanarische Inseln leg. H. Franz (2 우 우 NHMW); Isl. Can. Hierro, Umg. Parador $27^{\circ} 42.931$ N 1757.648W, 20 m, 3-5.VII.2011 E. Heiss (SZcoll); El Brezal, 800 m (Palm, 1976)

Macrocoma splendidula ssp. palmaensis Palm, 1977, n. stat. (Figs. 60 and 61)

M. occidentalis Palm, 1976: 102 (nec Escalera, 1914)

TYPE SPECIMENS. Holotype and Allotype OUNHM (not examined): no locality data [La Palma (Palm, 1976)].

Distribution AND Geonemic DATA. La Palma.

\section{ACKNOWLEDGEMENTS}

I wish to thank for the invoice of type specimens and other material: Dr Michael Geiser (The Natural History Museum, London), Dr Jaakko Mattila (Finnish Museum of Natural History), Dr Gloria Ortega (Museo de la Naturaleza y el Hobre, Museos de Tenerife), Dr Helena Shaverdo (Naturhistorisches Museum Wien), Dr Amoret Spooner (Oxford University Museum of Natural History). Particular thanks to Jan Pelikán, Antonio Machado Carrillo, Marion Mantič and Mauro Daccordi for sending specimens from their private collections and providing information about the host plant of some species. Thanks to Cristian Zoia for linguistic revision of the text and to the anonymous referees for their useful suggestions. 


\section{REFERENCES}

DACCORDI M., 1978 - Una nuova specie di «Macrocoma» («Coleoptera», «Chrysomelidae»). Pp. 155-158 in: Museo de Ciencias Naturales del Cabildo Insular de Santa Cruz de Tenerife. Contribucion al estudio de la Historia Natural de las Islas Salvajes. Resultados de la Expedicion cientifica 'Agamenon 76' (23 de febrero - 3 de Marzo de 1976). Aula de Cultura de Tenerife, Canary Islands: 1-209.

LindBerg H., 1950 - Beitrag zur Kenntnis der Käferfauna der kanarischen Inseln. Societas Scientiarum Fennica, Commentationes biologicae, 10: 1-20.

LindBerg H., 1953 - Zweiter Beitrag zur Kenntnis der Käferfauna der kanarischen Inseln. Societas Scientiarum Fennica, Commentationes Biologicae, 13 (12): 1-18.

Palm T., 1976 - Zur Kenntnis der Käferfauna der Kanarischen Inseln 17-18. Entomologica Scandinavica, 7 (2): $96-102$

PALM T., 1977 - Zur Kenntnis der Käferfauna der Kanarischen Inseln 17-18. Entomologica Scandinavica, 8 (3): 240.

WARChALOWSKI A., 2001 - A preliminary review of Western Palaearctic Macrocoma Chevrolat, 1837 (Coleoptera: Chrysomelidae: Eumolpinae). Genus, 12(4): 449-477.

Warchalowski A., 2003 - Chrysomelidae. The leaf-beetles of Europe and the Mediterranean area. Natura optima dux Foundation, Warszawa, 600 pp., 56 Figs pl.

WARchalowsKi A., 2010 - The Palaearctic Chrysomelidae. Identification keys. Volume 1. Natura optima dux Foundation, Warszawa, $629 \mathrm{pp}$.

Wollaston T. V., 1862 - Brief diagnostic characters of new Canarian Coleoptera. The Annals and Magazine of Natural History, ser. 3, 9: 437-442.

Wollaston T. V., 1864 - Catalogue of the Coleopterous Insects of the Canaries in the Collection of the British Museum. London, in $8 \mathrm{vo}, 648 \mathrm{pp}$. 

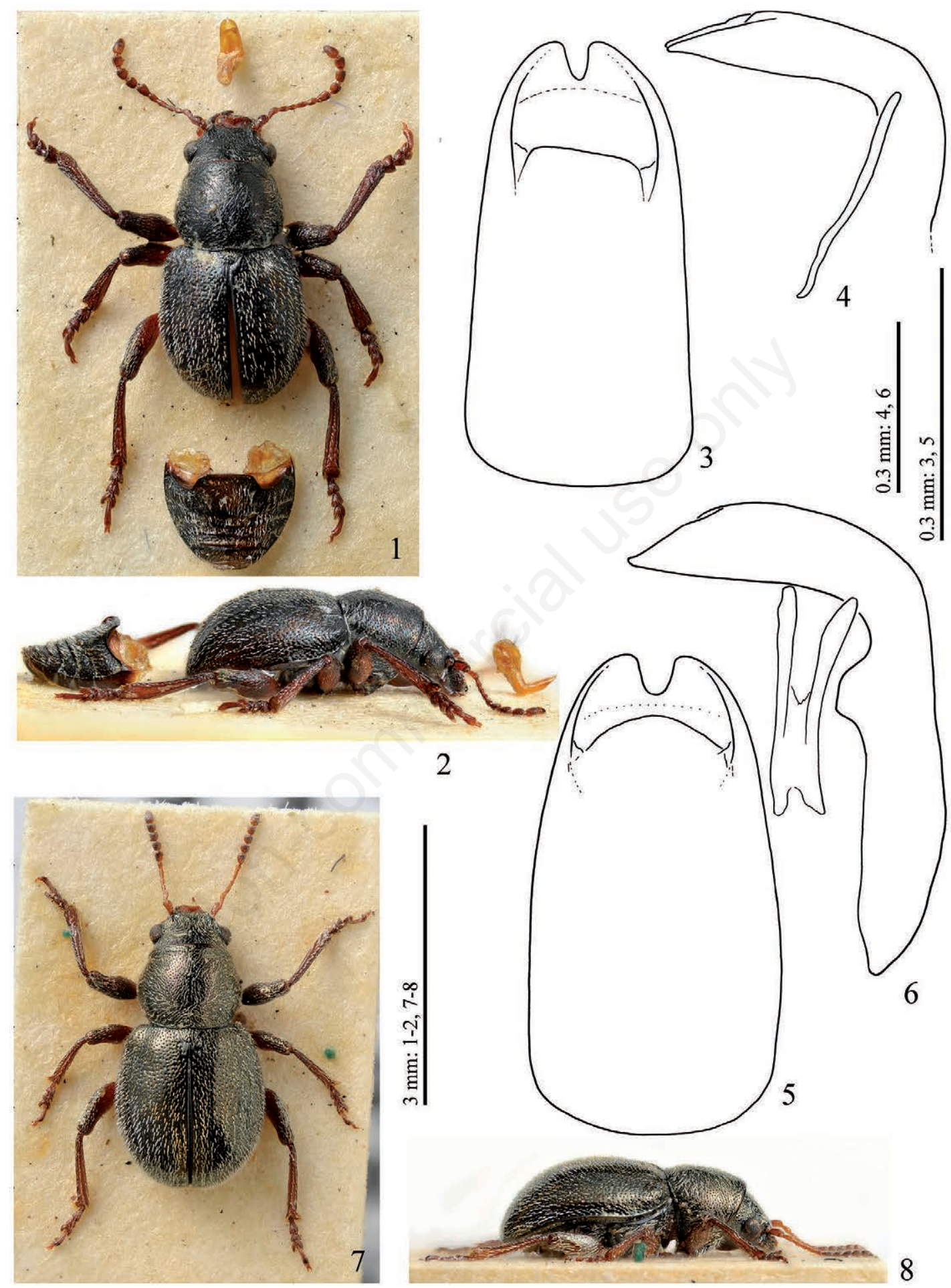

Figs. 1-8. Macrocoma divisa: 1 - ổ Syntype, dorsal view (Lanzarote; OUMNH); 2 - idem, lateral view; 3 - idem, aedeagus, dorsal view; 4 - idem, lateral view; 5 - aedeagus, dorsal view (Fuerteventura, Jandia, Valle de los Mosquiitos); 6 - idem, lateral view; 7 - 9 Syntype (Lanzarote; OUMNH), dorsal view; 8 - idem, lateral view. 


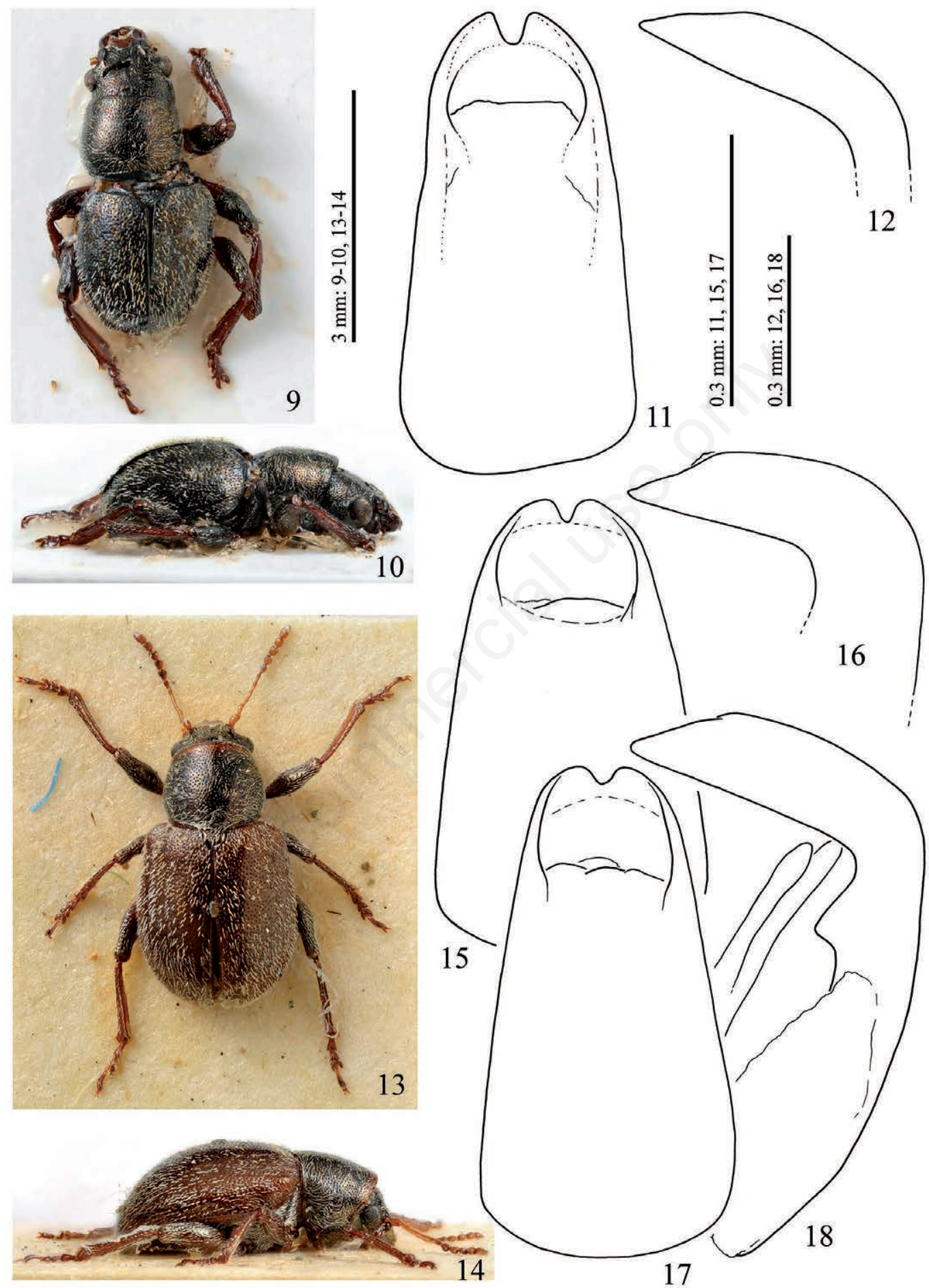

Figs. 9-18. Macrocoma oromiana: 9: ^̋ Holotype, dorsal view (Alegranza; MNHT); 10 - idem, lateral view; 11 - idem, aedeagus dorsal view; 12 - idem, lateral view. Figs. 13-18. Macrocoma dubia: 13 - $q$ Syntype (Fuerteventura; OUMNH), dorsal view; 14 - idem, lateral view; 15 - aedeagus, dorsal view (Lanzarote, Los Ancones); 16 - idem, lateral view; 17 - aedeagus, dorsal view (same locality as Figs 15-16); 18 - idem, lateral view. 

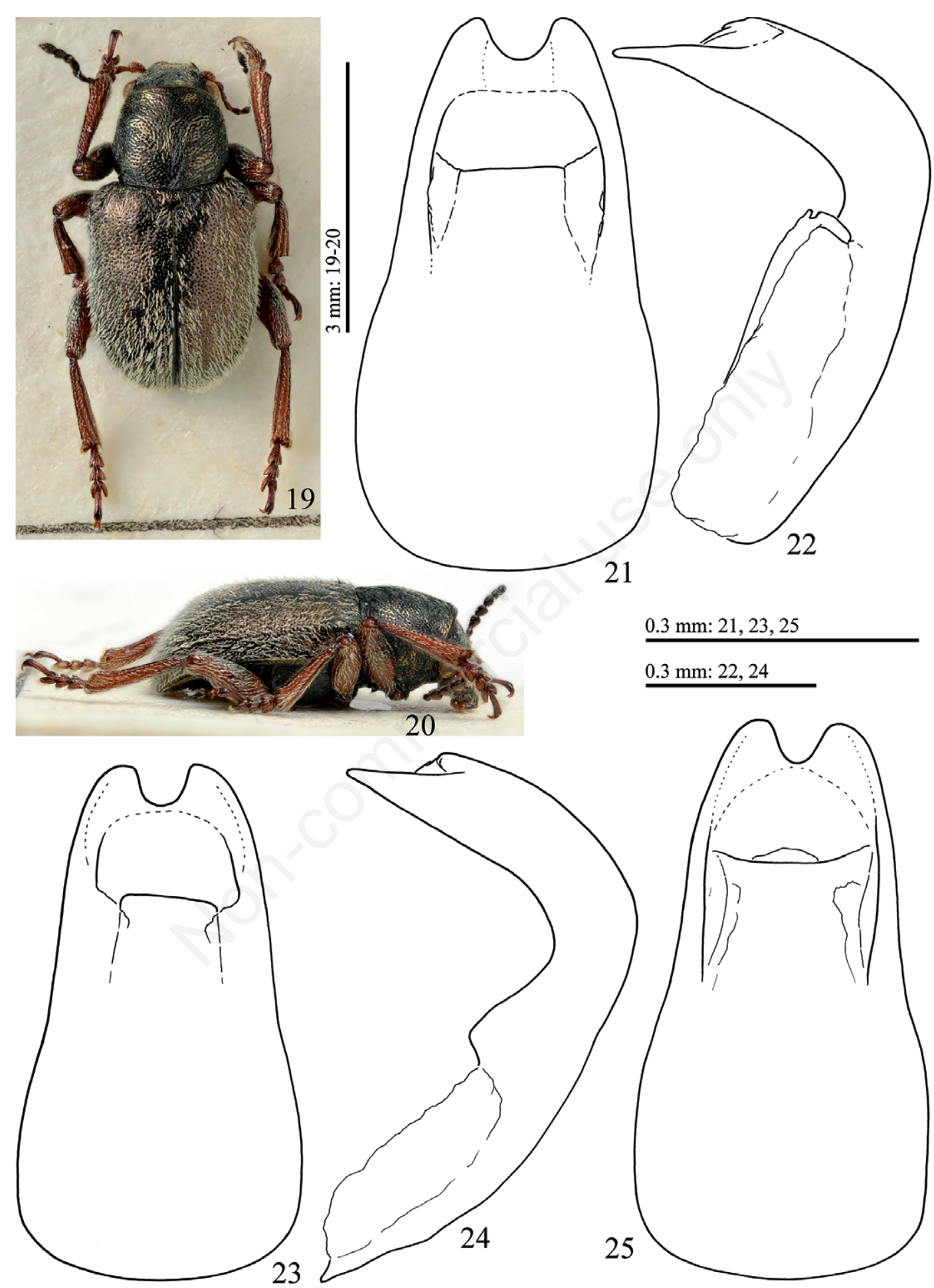

Figs. 19-25. Macrocoma latifrons: 19 - ổ Holotype, dorsal view (Tenerife, Puerto de S. Juan; FMNH); 20 - idem, lateral view; 21 - idem, aedeagus, dorsal view; 22 - idem, lateral view; 23 - aedeagus, dorsal view (Tenerife, Playa S. Juan, Guía); 24 - idem, lateral view; 25 - aedeagus, dorsal view (Tenerife, Los Gigantes). 

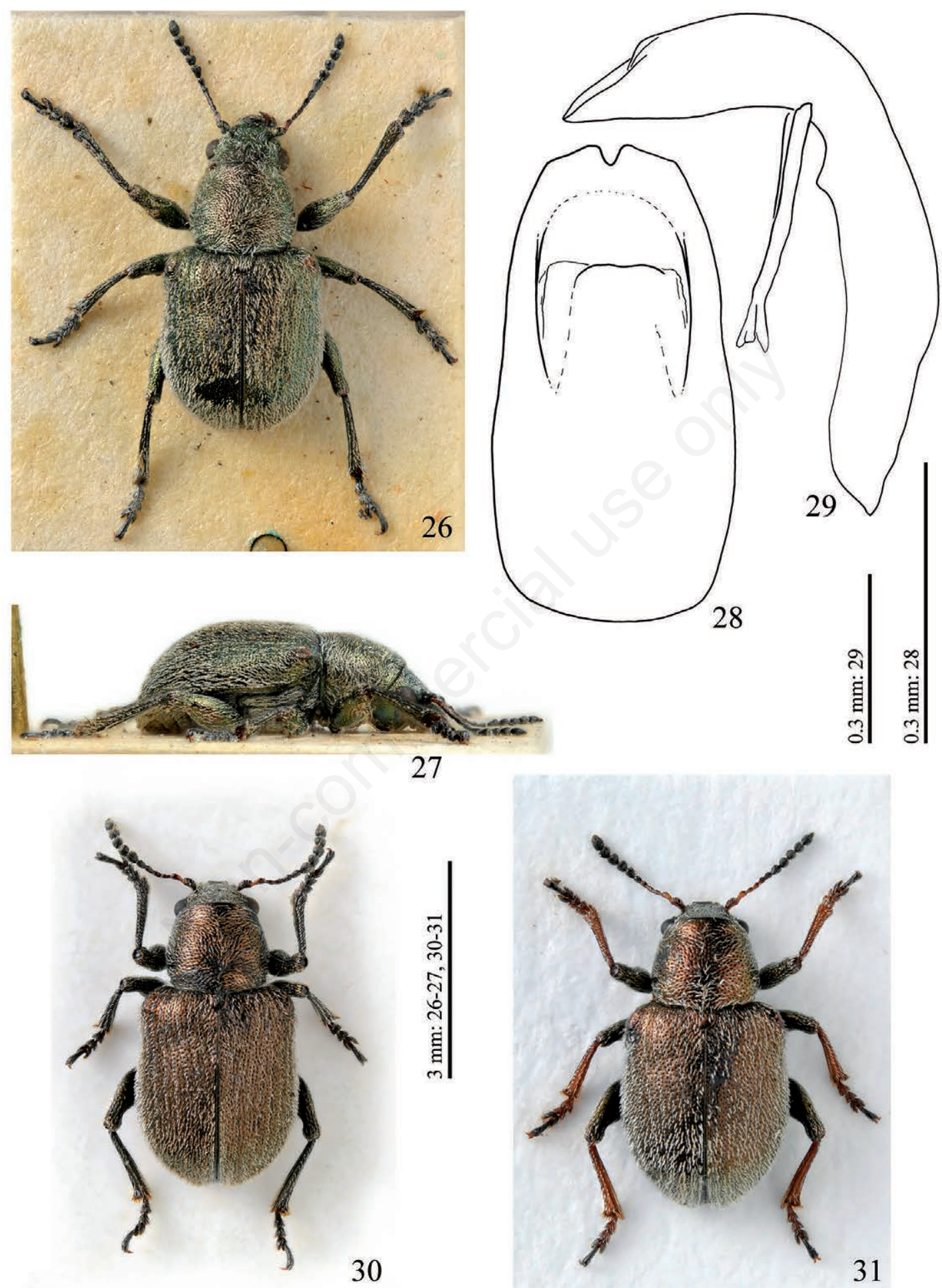

Figs. 26-31. Macrocoma obscuripes: 26 - \̋̂ Syntype, dorsal view (Gran Canaria; NHML); 27 - idem, lateral view; 28 - aedeagus, dorsal view (Gran Canaria, Artenara); 29 - idem, lateral view; 30 - , dorsal view (Gran Canaria, Artenara). Macrocoma pelikani n. sp., $q$ Paratype, dorsal view (Gran Canaria, Ingenio, Bco. de Guayadeque; JPcoll). 

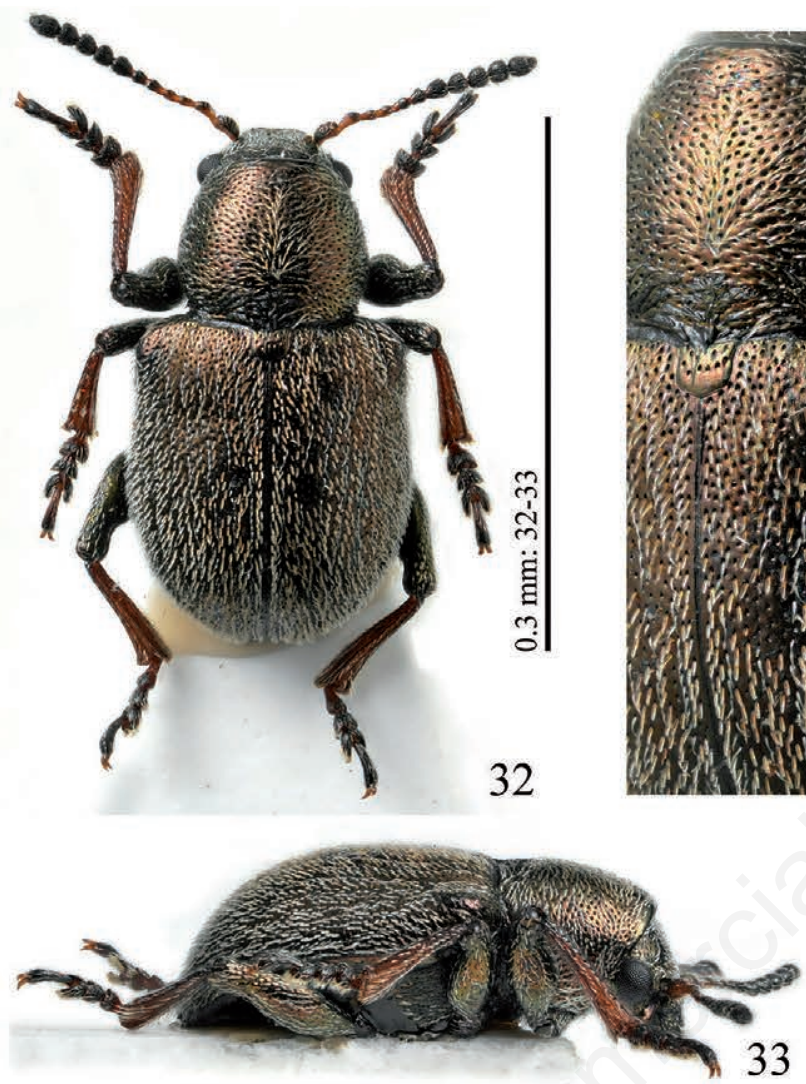

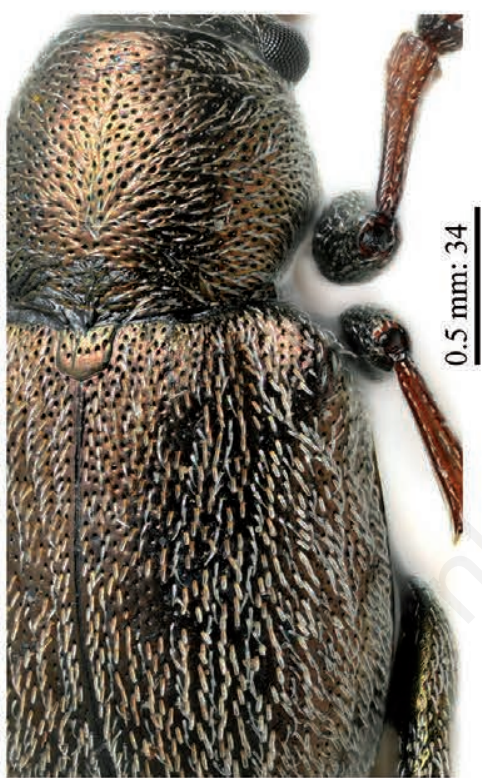

34
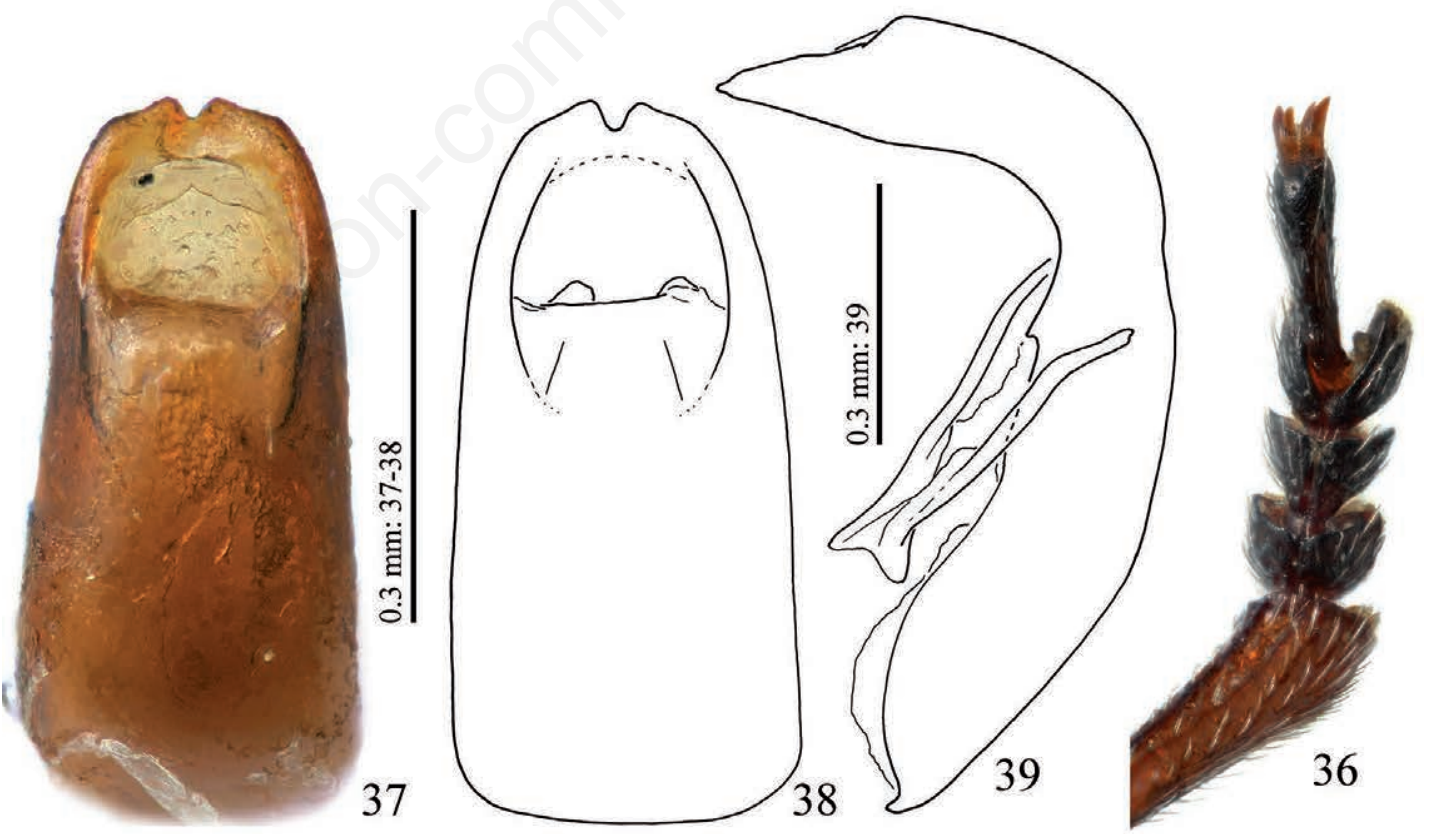

Figs. 32-39. Macrocoma pelikani n. sp.: 32 - đ̂ Holotype, dorsal view (Gran Canaria, Ingenio, Bco. de Guayadeque; MNHT); 33 - idem, lateral view; 34 - idem, surface of pronotum and elytra; 35 - left antenna; 36 - left protarsus; 37 - aedeagus, dorsal view; 38 - Paratype, aedeagus, dorsal view (same locality); 39 - idem, lateral view. 


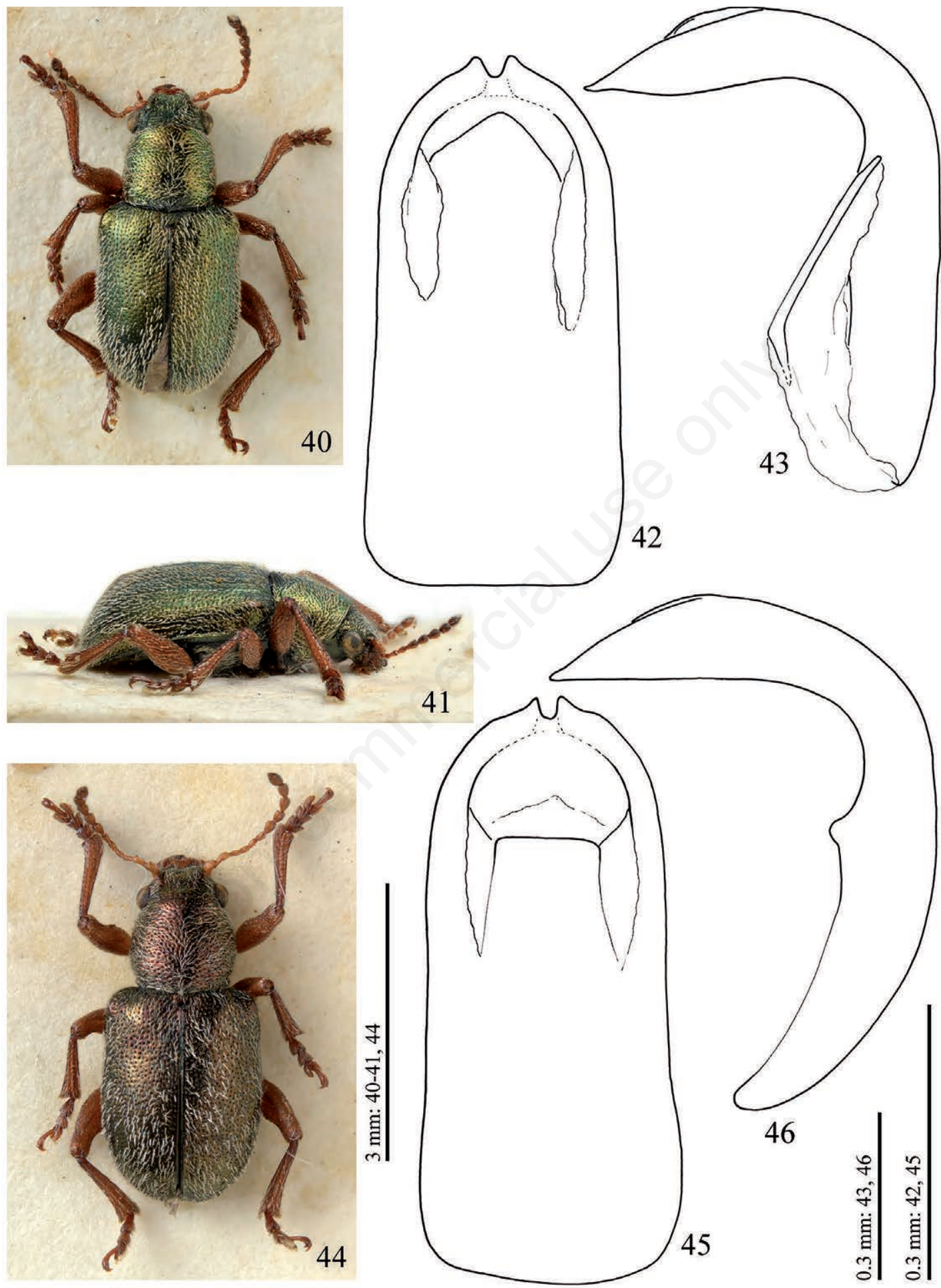

Figs 40-46. Macrocoma splendens: 40 - §o Holotype, dorsal view (Tenerife, supra Icod; FMNH); 41 - idem, lateral view; 42 idem, aedeagus, dorsal view; 43 - idem, lateral view; 44 - ô, dorsal view (La Palma, Santa Cruz); 45 - aedeagus, dorsal view (La Palma, Santa Cruz); 46 - idem, lateral view. 

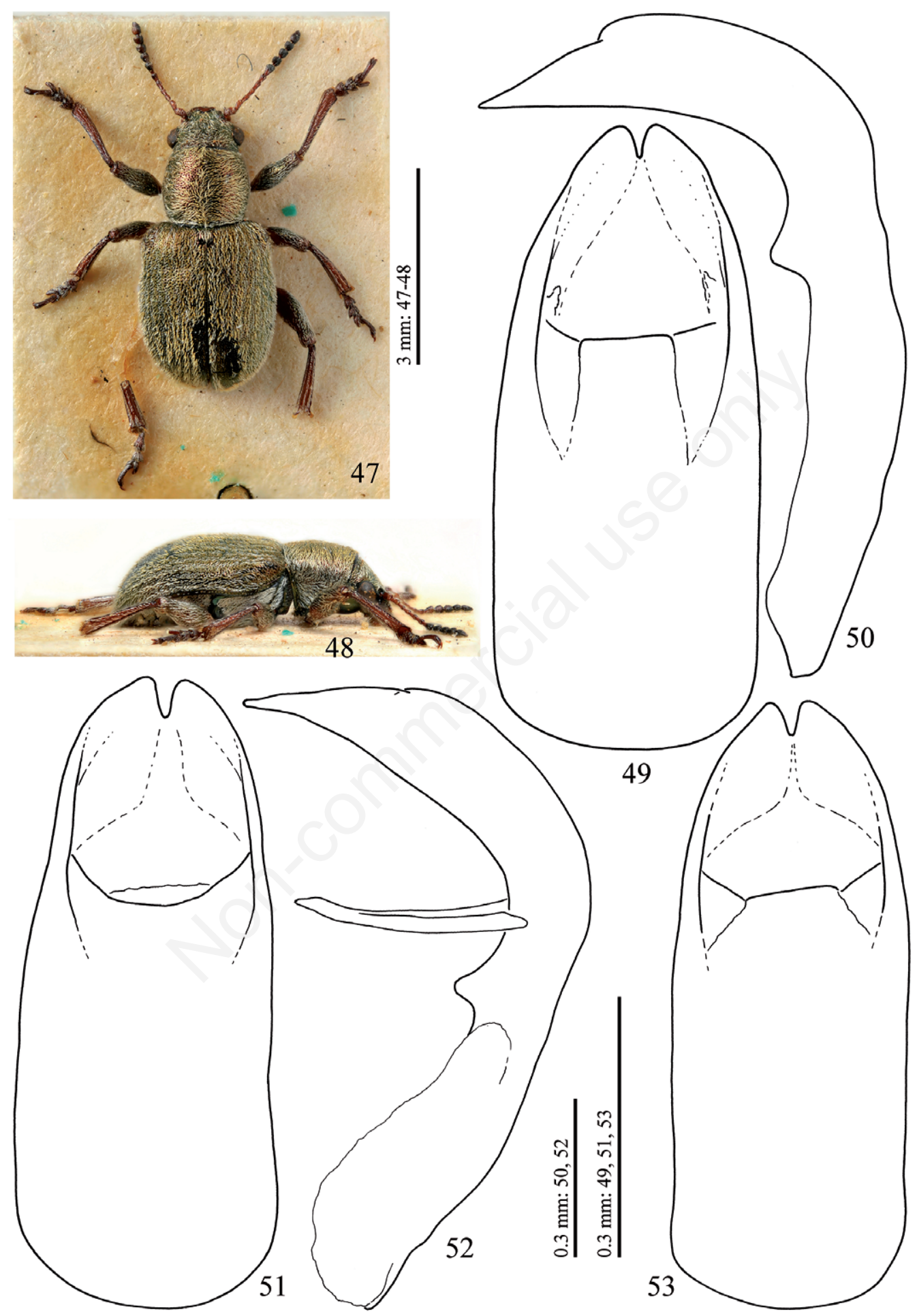

Figs. 47-53. Macrocoma splendidula splendidula: 47 - ô Lectotype, dorsal view (Gran Canaria; NHML); 48 - idem, lateral view; 49 - aedeagus, dorsal view (Gran Canaria, Tufia); 50 - idem, lateral view; 51 - aedeagus, dorsal view (Tenerife, Malpaís de Güímar); 52 - idem, lateral view; 53 - idem, aedeagus, dorsal view (Gran Canaria, Maspalomas). 

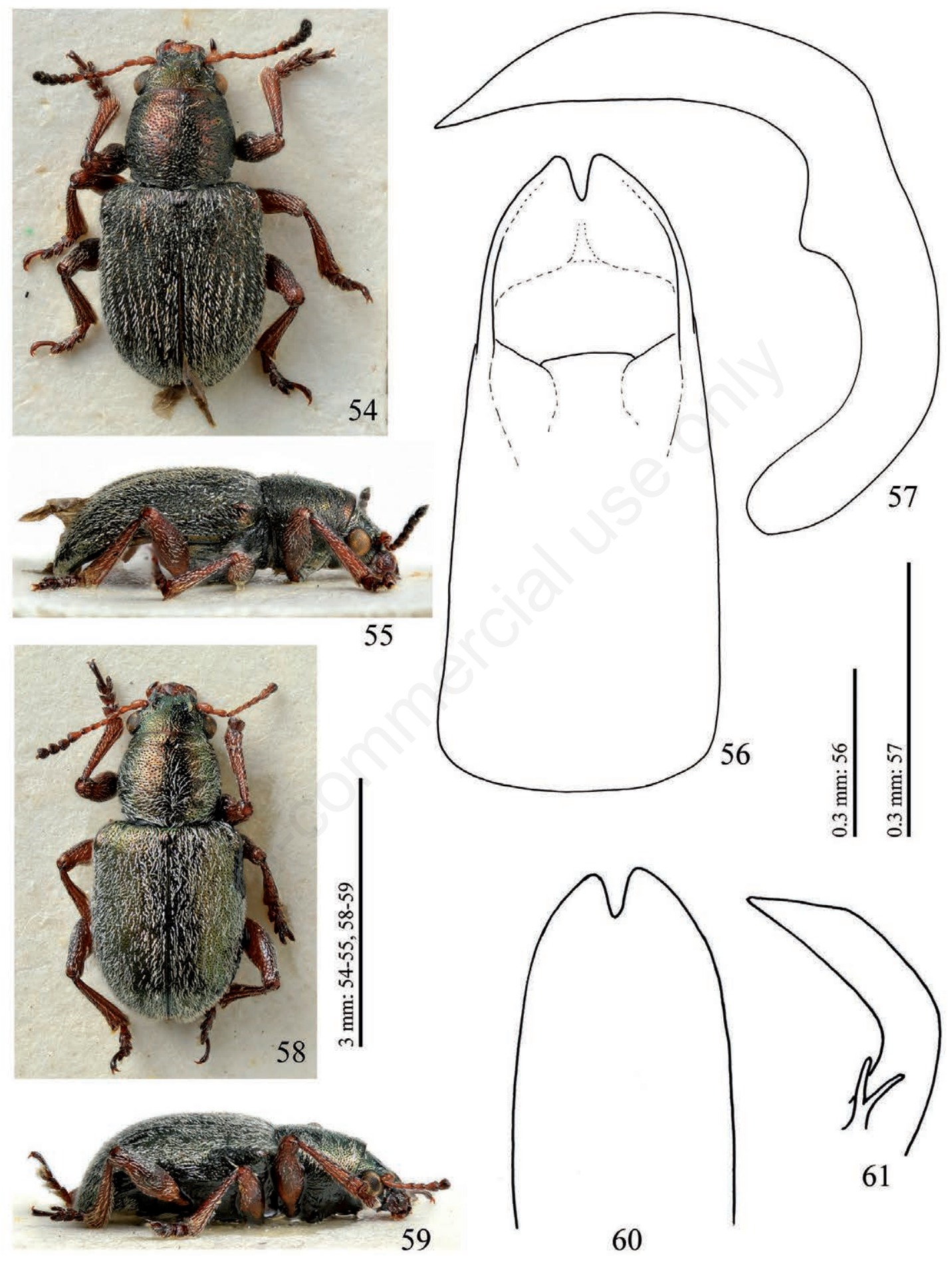

Figs. 54-61. Macrocoma splendidula franzi: 54 - ô Holotype, dorsal view (Isla del Hierro, Restinga; NHMW); 55 - idem, lateral view; 56 - idem, aedeagus, dorsal view; 57 - idem, lateral view; 58 - $q$ Allotype, dorsal view (Isla del Hierro, Restinga; NHMW); 59 - idem, lateral view. M. splendidula palmaensis: 60 - aedeagus, ventral view; 61 - idem, lateral view (re-drawn from Palm, 1976, not in scale). 


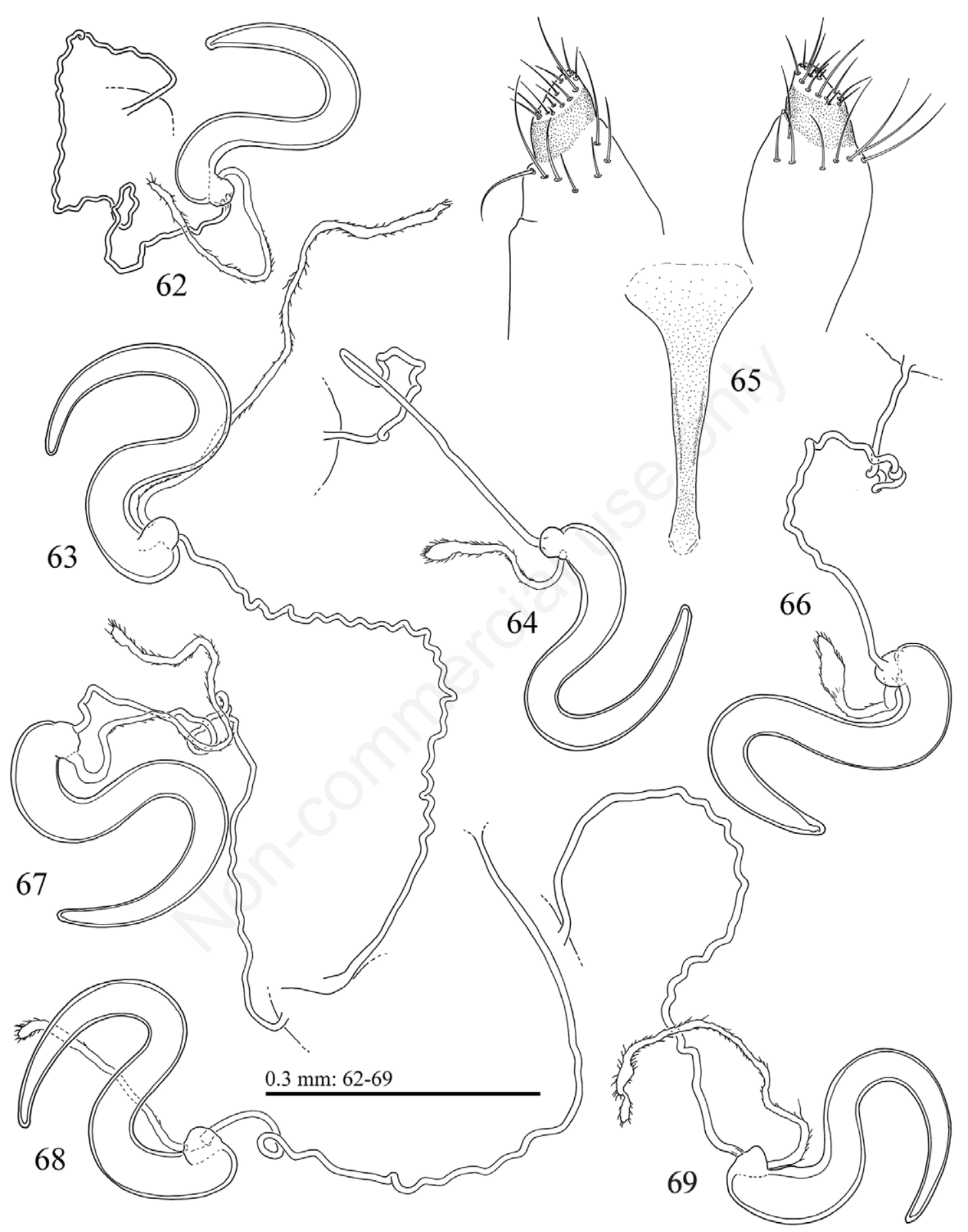

Figs. 62-69. 62 - Macrocoma divisa, spermatheca (Lanzarote, Los Ancones); 63 - M.splendidula splendidula, spermatheca (Gran Canaria, Tufia); 64 - M. obscuripes, spermatheca (Gran Canaria, Artenara); 65 - M. pelikani n. sp., styli and spiculum gastrale (Paratype - Gran Canaria, Ingenio, 35 km W Bco. de Guayadeque); 66 - idem, spermatheca; 67 - M. splendidula franzi, spermatheca (Isla del Hierro, Restinga); 68 - M. splendens, spermatheca (Paratype - Tenerife, Aqua Mansa); 69 - M. latifrons, spermatheca (Tenerife, Malpaís de Güímar). 


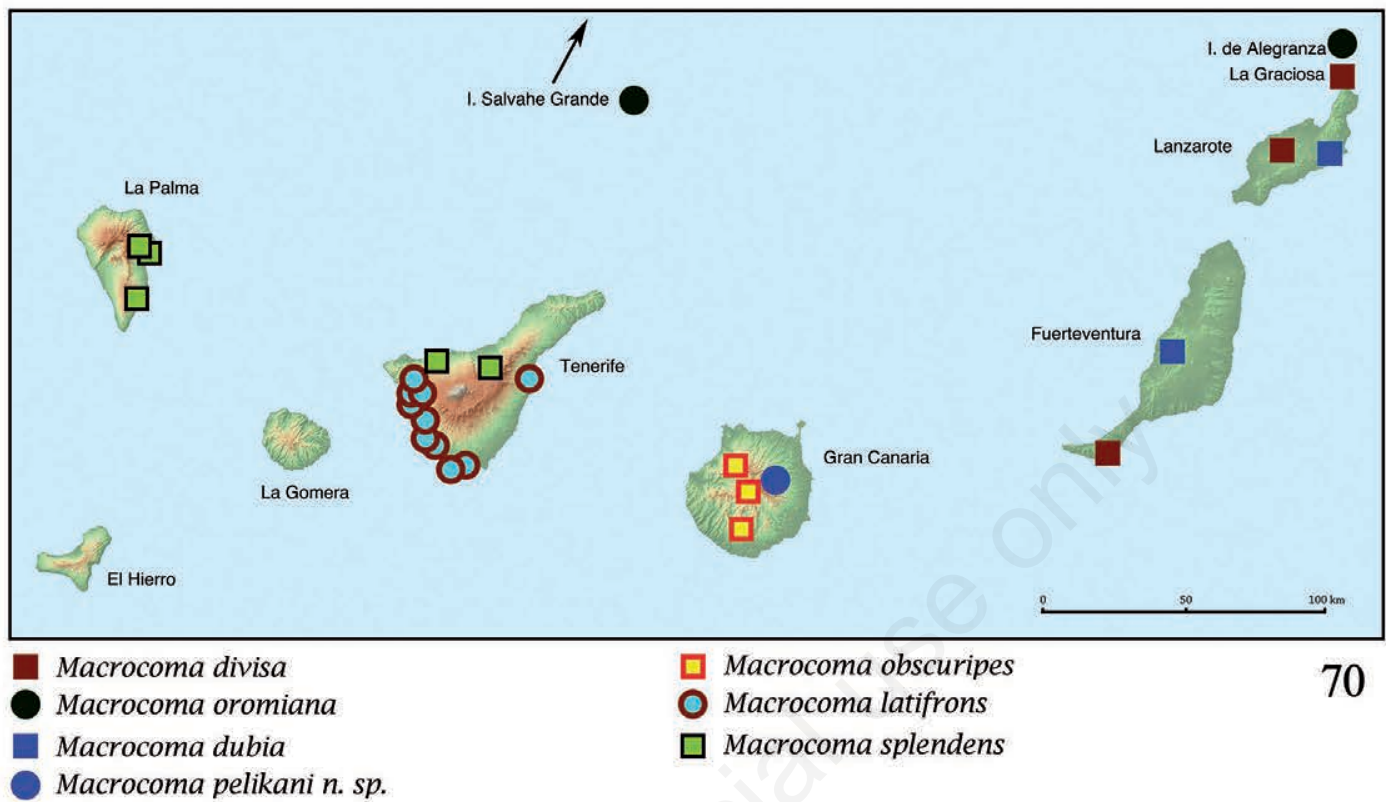

Macrocoma pelikani $n$. sp.

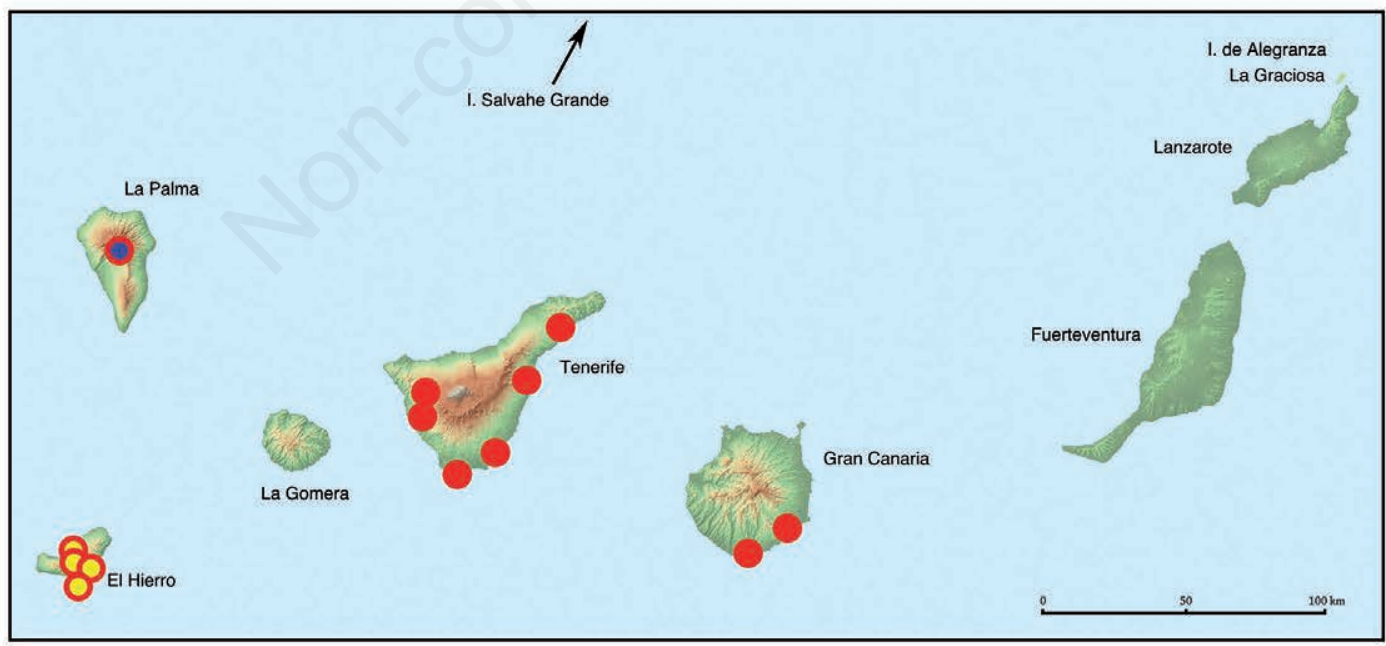

Macrocoma splendidula splendidula

Macrocoma splendidula franzi

Macrocoma splendidula palmaensis

Figs .70-71. 70 - distribution of Macrocoma divisa, M. oromiana, M. dubia, M. pelikani n. sp., M. obscuripes, M. latifrons and M. splendens; 71 - distribution of M. s. splendidula, M. s. franzi, M. s. palmaensis. 